\title{
A NOTE ON CUTANEOUS VENOUS BLOOD SUGAR DIFFER- ENCE IN NORMAL MALES AND FEMALES AND IN THYROID DISEASE
}

\author{
BY LEON JONAS 1
}

(From the William Pepper Laboratory of Clinical Medicine and the George S. Cox Research Institute of the University of Pennsylvania, Philadelphia)

(Received for publication August 17, 1932)

It has been well known since the publications of Foster (1) and of Hagedorn (2) that cutaneous blood obtained from a deep finger prick approximates arterial blood rather than venous blood in sugar concentration. The deeper the prick and the more freely the blood flows from the finger the more closely the cutaneous values approximate arterial values.

TABLE 1

Arterial, cutaneous and venous blood sugar values one hour after administration of 100 grams of glucose orally or $1 \mathrm{cc}$. of $1: 1000$ epinephrine subcutaneously

\begin{tabular}{|c|c|c|c|}
\hline & Arterial & Venous & $\begin{array}{c}\text { Difference } \\
\text { arterial-cutaneous }\end{array}$ \\
\hline After glucose.. & $\begin{array}{c}\text { mgm. per } 100 \text { cc. } \\
270 \\
160 \\
149 \\
160\end{array}$ & $\begin{array}{c}\text { mgm. per } 100 \text { cc. } \\
248 \\
108 \\
118 \\
123\end{array}$ & $\begin{array}{c}\text { mgm. per } 100 c c . \\
-3 \\
2 \\
2 \\
14\end{array}$ \\
\hline After epinephrine. & $\begin{array}{l}165 \\
142 \\
172\end{array}$ & $\begin{array}{l}157 \\
134 \\
146\end{array}$ & $\begin{array}{r}-2 \\
1 \\
14\end{array}$ \\
\hline
\end{tabular}

Table 1 shows the comparison of arterial, cutaneous and venous blood sugar values with our technique one hour after ingestion of 100 grams of glucose or after injection of $1 \mathrm{cc}$. of $1: 1000$ epinephrine in subjects without evidence of circulatory or metabolic disorder. Arterial blood was obtained from a brachial artery. Cutaneous blood was taken from a finger tip following a puncture with a pen point deep enough to give a free flow. Venous blood was drawn from the arm with only slight transient compression of the vein. Blood sugar was measured by the method of Hagedorn and Jensen (3). In two out of seven comparisons considerable discrepancy is noted between arterial and cutaneous values. The sugar content of cutaneous blood is not in our hands a reliable

1 Woodward Fellow in Physiological Chemistry. 
measure of that of arterial blood in individual determinations, although tending toward agreement with it in most instances. In the course of measurements of blood sugar concentration in cutaneous and venous blood at $\frac{1}{2}, 1$ and $1 \frac{1}{2}$ hours following ingestion of 100 grams of glucose by normal subjects we have noted a tendency toward higher cutaneousvenous differences in the females than in the males at the crest of the sugar curve.

TABLE 2

Cutaneous blood sugar value and cutaneous-venous difference after ingestion of 100 grams of glucose at the examination showing highest sugar value

\begin{tabular}{|c|c|c|c|c|c|}
\hline & \multicolumn{2}{|c|}{ Males } & & \multicolumn{2}{|c|}{ Females } \\
\hline & Cutaneous & $\begin{array}{l}\text { Difference } \\
\text { cutaneous- } \\
\text { venous }\end{array}$ & & Cutaneous & $\begin{array}{l}\text { Difference } \\
\text { cutaneous- } \\
\text { venous }\end{array}$ \\
\hline \multirow[t]{3}{*}{ Normals. . } & $\begin{array}{c}\text { mgm. per } \\
100 \text { cc. } \\
198 \\
211 \\
173 \\
159\end{array}$ & $\begin{array}{c}\text { mgm. per } \\
100 \text { cc. } \\
48 \\
32 \\
26 \\
25\end{array}$ & Normals.......... & $\begin{array}{c}\text { mgm. per } \\
100 \text { cc. } \\
203 \\
135 \\
135 \\
137\end{array}$ & $\begin{array}{c}\text { mgm. per } \\
100 \text { cc. } \\
61 \\
42 \\
39 \\
38\end{array}$ \\
\hline & 148 & 24 & & 144 & 36 \\
\hline & $\begin{array}{l}182 \\
190 \\
179 \\
182\end{array}$ & $\begin{array}{l}22 \\
20 \\
18 \\
13\end{array}$ & & $\begin{array}{l}135 \\
172 \\
201 \\
124\end{array}$ & $\begin{array}{l}33 \\
32 \\
31 \\
28\end{array}$ \\
\hline \multirow[t]{5}{*}{ Hyperthyroid....... } & $\begin{array}{l}281 \\
239\end{array}$ & $\begin{array}{r}49 \\
0\end{array}$ & \multirow[t]{2}{*}{ Hyperthyroid. } & \multirow{2}{*}{$\begin{array}{l}174 \\
219 \\
355 \\
262 \\
133\end{array}$} & \multirow{2}{*}{$\begin{array}{l}49 \\
37 \\
30 \\
30 \\
27\end{array}$} \\
\hline & & & & & \\
\hline & & & & 217 & 27 \\
\hline & & & & $\begin{array}{l}230 \\
274 \\
232 \\
234 \\
189\end{array}$ & $\begin{array}{r}22 \\
21 \\
15 \\
10 \\
-4\end{array}$ \\
\hline & & & Hypothyroid....... & $\begin{array}{l}223 \\
206 \\
171 \\
220 \\
181\end{array}$ & $\begin{array}{l}89 \\
80 \\
49 \\
46 \\
40\end{array}$ \\
\hline
\end{tabular}

This is shown in Table 2. It includes as "normals" the values on 9 male and 9 female medical students or members of the laboratory staff who, with the exception of one male who was 40 , varied in age between 18 
and 30. The cutaneous and venous blood, taken fasting, contained nearly the same concentration of sugar. The cutaneous-venous difference became definite as the blood sugar rose. The tendency toward greater cutaneous-venous difference at the crest of the curve in the females than in the males was associated with lower rather than higher sugar values in cutaneous and venous blood in the females.

In Table 2 are shown also the cutaneous-venous differences at the crest of the curve following ingestion of 100 grams of glucose in 11 female and 2 male patients with hyperthyroidism and in 5 females with hypothyroidism. In about half the patients with hyperthyroidism the cutaneous-venous differences are lower than normal. In most of the hypothyroid patients the cutaneous-venous difference is high. No consistent difference in the cutaneous sugar values is to be noted in the two groups.

\section{BIBLIOGRAPHY}

1. Foster, G. L., J. Biol. Chem., 1923, 1v, 291. Studies on Carbohydrate Metabolism. I. Some Comparisons of Blood Sugar Concentrations in Venous Blood and in Finger Blood.

2. Hagedorn, H. C., Ugesk. f. Laeger, 1920, lxxxii, 796. Om Sukkerprocenten i Vena mediana cubiti.

3. Hagedorn, H. C., and Jensen, B. N., Biochem. Ztschr., 1923, cxxxv, 46. Zur mikrobestimmung des Blutzuckers mittels Ferricyanid. 